\title{
Destination Characteristics that Drive Hotel Performance A State-of-the-Art Global Analysis
}

\author{
Assaf, A. George; Josiassen, Alexander; Woo, Linda; Agbola, Frank Wogbe; Tsionas, Mike
}

Document Version

Accepted author manuscript

Published in:

Tourism Management

DOI:

10.1016/j.tourman.2016.12.010

Publication date:

2017

License

CC BY-NC-ND

Citation for published version (APA):

Assaf, A. G., Josiassen, A., Woo, L., Agbola, F. W., \& Tsionas, M. (2017). Destination Characteristics that Drive Hotel Performance: A State-of-the-Art Global Analysis. Tourism Management, 60, 270-279.

https://doi.org/10.1016/j.tourman.2016.12.010

Link to publication in CBS Research Portal

\section{General rights}

Copyright and moral rights for the publications made accessible in the public portal are retained by the authors and/or other copyright owners and it is a condition of accessing publications that users recognise and abide by the legal requirements associated with these rights.

Take down policy

If you believe that this document breaches copyright please contact us (research.lib@cbs.dk) providing details, and we will remove access to the work immediately and investigate your claim. 


\section{Destination Characteristics that Drive Hotel Performance: A State-of-the-Art Global Analysis}

\section{A. George Assaf, Alexander Josiassen, Linda Woo, Frank Wogbe Agbola, and Mike Tsionas}

Journal article (Accepted manuscript*)

\section{Please cite this article as:}

Assaf, A. G., Josiassen, A., Woo, L., Agbola, F. W., \& Tsionas, M. (2017). Destination Characteristics that Drive Hotel Performance: A State-of-the-Art Global Analysis. Tourism Management, 60, 270-279. 001:

10.1016/j.tourman.2016.12.010

DOI: 10.1016/j.tourman.2016.12.010

* This version of the article has been accepted for publication and undergone full peer review but has not been through the copyediting, typesetting, pagination and proofreading process, which may lead to differences between this version and the publisher's final version AKA Version of Record.

Uploaded to CBS Research Portal: February 2019

(C) 2019. This manuscript version is made available under the CC-BY-NC-ND 4.0 license http://creativecommons.org/licenses/by-nc-nd/4.0/ 


\title{
Destination Characteristics that Drive Hotel Performance: A State-of-the-Art Global
}

\section{Analysis}

\begin{abstract}
The increased market saturation and competition in both domestic and international tourism destinations has renewed interest among hotel operators in identifying the key drivers of hotel performance. This paper presents a comprehensive analysis of the determinants of hotel performance and their relative importance across multiple tourist destinations. We employ a two-step estimation method to identify key determinants of hotel performance, using a rich sample of international hotels. Our empirical analyses show that the main drivers of hotel performance are the quality of educational system, government support, disposable income, and number of international arrivals within a tourism destination. Results indicate that the most important barriers to hotel performance are the competition among accommodation providers, tax rate and fuel price. We argue for the need for hotel providers to develop strategies that take into account the key drivers and barriers to enhancing hotel performance in an ever-changing global tourism sector.
\end{abstract}

Keywords: Determinants of Hotel Performance, Tourism Destinations, International Hotel Operators, Sales per Room, Sales per Outlet

\section{Introduction}

The growing competition among hotel providers and the continuous pressure resulting from market saturation has necessitated the need for greater performance control in the hotel industry (Assaf, Josiassen, \& Cvelbar, 2012; Pavia, Gržinić, \& Floričić, 2014; Wang, Chen, \& Chen, 2012). As global hotel brands continue to expand internationally, selecting the next attractive tourist destination that will offer the best returns has become one of the most highly debated and contentious issues facing hotel providers globally (Yang, Wong, \& Wang, 2012). 
Although extensive research has been undertaken to establish the importance of destination characteristics in the strategic decision making process of hotels, research is sparse on identifying and ranking the determinants of hotel performance and ranking these drivers of hotel performance globally. In a recent meta-analysis, Assaf and Josiassen (2015) emphasized that while more than 50 empirical studies have measured and compared the performance of international hotels, the study of determinants of hotel performance within the tourism industry on a global scale have been limited. Although the study by Assaf, Josiassen and Agbola (2015) identified the locational factors that make destinations attractive to international hotel operators, the focus was on locational factors that hotel chain providers consider as key in making decisions about investing in a destination. Despite the clear contribution of the study by Assaf et al (2015) it stopped short of exploring how these destination factors influence hotel performance.

The focus of the present study is to bridge this knowledge gap by identifying destination characteristics that influence hotel performance. Further, we extend the analysis by ranking these destination characteristics. To the best of our knowledge, this is the first study to undertake a comprehensive global analysis of the drivers and the ranking of destination characteristics that drive hotel performance. Specifically, we aim to address two key questions: (i) What are the key determinants of hotel performance globally? and; (ii) how does each determinant rank in terms of its effect on hotel performance? Some studies have linked hotel performance to various types of determinants (e.g., size, and star rating). These studies, however, only explored a small number of determinants and were restricted to specific regions or destinations (e.g., Alias \& Tan, 2014; O’Neill \& Mattila, 2006; Oliveira, Pedro, \& Marques, 2013; Sainaghi, 2011). As Barros and Dieke (2008) emphasize, the differences in characteristics of tourism destinations makes it necessary to consider hotel performance over a period of time and across multiple tourism destinations in order to 
articulate an effective hotel strategy and tourism policy. Employing differing market characteristics and trends over time provides sound theoretical framework for analyzing the determinants of hotel performance within a global context (Assaf \& Josiassen, 2012). In a changing global economy, understanding the determinants of hotel performance at an international level is critical. Understanding the factors influencing hotel performance would provide strategic information to assist hotel operators in making informed decision about where to locate hotels to achieve the greatest performance.

The rest of this paper is structured as follows. In Section 1, a large pool of determinants was identified. The pool was sourced via: a) a thorough review of the tourism and hospitality literature; and b) a series of interviews with hotel managers. Then, actual data was collected on these determinants from the international locations of a large sample of hotels. In Section 2, the hotel performance determinants (HPD) framework was developed to test and rank each of the determinants of hotel performance. In Section 3, the article discusses the various determinants and their impact on hotel performance. Section 4 presents the data. Sections 5 and 6 set out the results, discussion and implications. The article discusses how the findings can be used to guide future research on hotel performance and advance the state of international hotel benchmarking. Both existing hotels and potential new entrants will benefit from the reported insights to better tailor their strategies and investments around the determinants that have the highest impact on hotel performance and to identify attractive locations that would provide important advantages in terms of the determinants identified in this study.

\section{Research Framework}

Following the approach of related studies in other industries (Creswell, 2009), this study used a two-step approach (i.e. a literature review and expert interviews) to identify the 
determinants $^{1}$ of hotel performance. The advantage of this method is that it does not rely on the assumptions of the researchers, but sources the potential determinants in a first exploratory step. The second step then provides a quantitative analysis based on these determinants. The literature suggested to first include categories observed by previous research (Srnka \& Koeszegi, 2007; Weber, 2004). Accordingly, the industry and academic literature on hotel performance was reviewed. Using search terms such as "locational factors", "hotel performance", "hotel location" in several major search engines like Google Scholar and Ebsco a pool of relevant articles was identified and reviewed. This interdisciplinary review resulted in the extraction of 21 determinants. Based on the literature, these determinants were then classified into six drivers ${ }^{2}$. Next, 11 in-depth interviews were conducted with the regional managers of major hotel companies such as the JW Marriott, the Hyatt, the Best Western, the Hilton, the Sheraton, Le Meridien and the Westin. The approach of Johnson and Vanetti (2005) was adopted to select interview participants and hotels were selected that had a high presence in international markets. All of the hotels selected had a strong international reputation and constantly target new locations for foreign expansion. During the summer 2015, each regional manager was asked (via an open-ended question) to provide a list of determinants that they viewed as the most important drivers of hotel performance. The interview data was analyzed, and the content ordered and aggregated using the method commonly used in the area to identify such categories (Assaf et al., 2015). The final list of determinants contained a mixture of those identified in the literature those identified by the interview participants.

Overall, the interview participants' answers about determinants closely overlapped with the results of the literature review; however, an additional two determinants were

\footnotetext{
${ }^{1}$ Determinants refer to the variables affecting hotel performance.

${ }^{2}$ The drivers represent the broader classification of these determinants. We follow closely the classification of the World Economic Forum, Assaf and Joiassen (2012) and Assaf et al. (2015).
} 
identified from the literature. Table 1 lists the all determinants identified from the literature and also indicates whether the interview participants highlighted these determinants.

All these determinants were then classified under the drivers identified in the literature review (Assaf \& Josiassen, 2015; Crouch \& Ritchie, 1999). Table 2 lists the determinants and their associated drivers. The two-step approach identifying the determinants of hotel performance resulted in a final pool of 21 determinants (that were then classified under six drivers). Given the large number of determinants, the relationship between each of the determinants and hotel performance is not discussed; rather each driver is considered in detail and examples are provided about some of the determinants.

\section{Drivers of Hotel Performance}

\subsection{General Economic Condition}

Interview participants agreed that "general economic conditions" (e.g., Gross Domestic Product (GDP) growth, tax rates, exchange rates, disposable incomes, and fuel prices) can significantly affect hotel performance and demand for hotels. For example, during the recent economic crisis, the majority of hotel companies experienced a sharp decrease in occupancy rates and the revenue generated per available room (Chen, 2010; IBISWorld, 2014; Kosova \& Enz, 2012; MarketLine, 2015b; O’Neill \& Mattila, 2006; Zheng, 2014). Previous research has also shown that economic conditions can influence travel spending and the revenue performance of international hotels (Chen, 2007, 2010; Chen, Kim, \& Kim, 2005; IBISWorld, 2014). Factors related to economic development and stability (e.g., disposable income) have been found to be strong determinants of hotel performance across several industries (IBISWorld, 2014, 2015; Kosova \& Enz, 2012; MarketLine, 2014; Naude \& Saayman, 2005). Hotel demand also appears "to be sensitive to economic growth and macroeconomic stability" (Naude \& Saayman, 2005, p. 371). It is arguable that the level of 
economic development affects the nature and level of competition at various hotel locations; for example, a strong economy will encourage "more foreign investments in the industry and also enable more government support" (Assaf \& Josiassen, 2012, p. 390). This undoubtedly affects hotel performance and could determine the number of hotel companies entering and exiting the industry.

\subsection{Safety and Stability}

Interviewees cited the safety and stability condition of a particular location as a critical determinant of hotel performance. Further, if a negative perception is created about a particular location, hotel performance can be affected both in the short and long term (Chen et al., 2005; MarketLine, 2015c). One interview participant emphasized the current negative image that Kuala Lumpur has in the international media and noted that this had affected hotel performance. This negative perception was "caused by three aviation incidents with Malaysia registration aircraft and more recently, the alleged affiliations with IS (ISIS) of Malaysian nationals." Another interview participant noted that several terrorist attacks around the world had negatively affected the perceptions of international customers and resulted in fewer guests staying at international hotels such as the Marriott, the InterContinental, and the Hilton (MarketLine, 2015a, 2015b, 2015c).

Considerable evidence exists in the literature about the link between safety and the stability of a particular destination and hotel performance (George, 2003; Harper, 2001). Kosova and Enz (2012, p. 308) found that the "9/11 terrorist attacks had an abrupt and dramatic impact in reducing hotels' occupancy, and rates briefly followed occupancy downward." Research on return visits has also shown a positive link between tourists' intentions to return and the safety and stability of a particular destination (Alegre \& Cladera, 2006). Factors related to safety and stability such as terrorists' attacks, crime rates, and 
natural disasters have also been found to have a negative effect on hotel stock returns and prices (Assaf \& Josiassen, 2012; Chen, 2007; Chen et al., 2005; O’Neill \& Mattila, 2006).

\subsection{Market Supply and Demand}

The balance of supply and demand in the market affects hotel performance across locations. As investments in hotels increase around the world, hotels need to maintain strong performance and ensure that they are located in areas with high tourism demands and strong market performance to meet challenges from competitors. As one interview participant observer: "there are more hotels being built year after year in most primary and secondary markets. Hotels that would run $80 \%$-year round are running $50-60 \%$. The demand is not growing with the supply, but this does not seem to be stopping developers." Several participants also raised the issue of market saturation. One interview participant stated that: "New York keeps adding more and more hotel rooms and now this is negatively affecting us as well-Overall Negative." Clearly, hotels need to continuously assess the existing market capacity both in terms of the number of hotels and the number of rooms before entering a new location (Assaf et al., 2015; Chung \& Kalnins, 2001; IBISWorld, 2014; MarketLine, 2015d; Tavitiyaman, Qu, \& Zhang, 2011; Yang et al., 2012). Given the continuous increase in hotel development, hotels cannot afford to be located in areas with low tourism demand or weak industry performance (IBISWorld, 2014; Zheng, 2014).

Ample evidence exists on the relationship between market capacity and hotel performance; for example, Zheng (2014) showed that the rapid growth of room supply and overdevelopment in the United States (U.S.) hotel market caused a significant decrease in RevPAR (revenue per available room) following the recession. Baum and Mezias (1992) examined the impact of increasing hotel supply in a particular cluster on the performance of the Manhattan hotel industry. They found that while hotels located in highly saturated 
locations experience a higher failure rate, they can also benefit from the positive externalities (e.g., knowledge, and marketing) generated by other hotels. Similarly, Peiró-Signes SegarraOña, Miret-Pastor, and Verma (2015) noted that being located in an area with high room supply does not necessarily harm hotel performance. Hotels can adapt well and benefit from the agglomeration benefits provided by other hotels in the area.

\subsection{Tourism Regulation and Support}

It is critically important that hotels are located in areas with strong travel and tourism support and transparent regulations. The security requirements imposed by the U.S. government following the $9 / 11$ terrorist attacks caused a significant decrease in tourism receipts and a decrease of more than $30 \%$ in the US share of the global market (MarketLine, 2015d). One interview participant operating in the Canadian market emphasized the importance of having government support both regarding funding and regulations. This interview participant noted that the government's lack of supportive destination marketing strategies (e.g., reducing worldwide budgets for marketing Canada and ignoring hotel industry lobby groups) led to "frustration" in the hotel industry and forced some hotels to "give up" their business. Such claims were well supported by the literature (Assaf \& Josiassen, 2012; Assaf et al., 2015; Sainaghi \& Baggio, 2014). Assaf et al. (2015, p. 332) emphasized that higher government support can help "improve hotel demand and increase the sources of revenue."

\subsection{Quality of Infrastructure}

Several of the interview participants emphasized a link between hotel performance and infrastructure quality (e.g., information and communication technology (ICT), airlines, roads, and airports) in a particular location. Infrastructure quality can improve the 
attractiveness of a destination and affect guests' intentions to return to a particular location (Beerli \& Martín, 2004; Faulkner, Oppermann, \& Fredline, 1999). Conversely, areas with poor infrastructure are often seasonally rigid and unable to meet tourism demands in high seasons (Briassoulis, 2002).

Several studies have illustrated the impact of destination infrastructure on hotel performance (Leonidou, Leonidou, Fotiadis, \& Zeriti, 2013; Sainaghi \& Baggio, 2014). Notably, ICT has become increasingly important in recent years (Kamasivayan, Enz, \& Siguaw, 2001; Karadag, Cobanoglu, \& Dickinson, 2009; Siguaw, Enz, \& Namasivayam, 2000; Sirirak, Islam, \& Khang, 2011). Several interview participants noted that the Internet and mobile technologies have proven very beneficial to their hotel's bottom line. ICT has changed booking methods, improved productivity, and enabled hotels to easily monitor guests' complaints (e.g., via online reviews and social media). Major players in the hotel industry such as Marriott and Intercontinental have already invested in new mobile technologies in North America and China where a large number of mobile devices users live. This has helped to increase their brand reputation, preference, and revenues (MarketLine, 2015b, 2015c).

\subsection{Labor Skills and Training}

It is widely acknowledged that the hotel industry is labor intensive and depends on superior labor skills to maintain high demand (Cho, Woods, Jang, \& Erdem, 2006; IBISWorld, 2014). Labor training is also "essential in delivering the strategic objectives set by managers in the industry, and it plays an important role in improving the knowledge, skills, and abilities of employees within the industry" (Assaf \& Josiassen, 2012, p. 391). Labor training represents a core competence of hotel firms and is positively associated with hotel performance (Assaf \& Josiassen, 2012; Assaf et al., 2015; Cho et al., 2006; Sun, Aryee, \& 
Law, 2007; Tavitiyaman et al., 2011). Hotels located in destinations with highly qualified human resources can improve their performance by reducing their training costs and upgrading their value chain (Assaf et al., 2015). Further, international hotel firms might prefer to be located in countries with highly qualified human resources, as employing individuals with the knowledge and skills critical to firm performance enables them to gain access to knowledge sharing and spill-overs (Shaw \& Williams, 2009).

The majority of the interview participants discussed the importance of human capital (e.g., well-educated and trained employees) in improving hotel performance. Some interview participants noted that "talented associates" was the most important factor in their hotel's success. A workforce of employees with a variety of skills, knowledge, and innovative abilities gives many hotels with a competitive edge.

\section{Data and Analysis}

The main goal of this paper is to assess the determinants of hotel performance. Two measures of hotel performance were considered, namely, sales per room and sales per outlet. Many of the hotel companies included in the sample have several branches in the same location. Thus, including sales per outlet reflected the average performance of each of these branches. However, sales per room is considered a better measure of firm performance as it is less sensitive to size differences. The interview participants confirmed these two dependent variables as measures of firm performance. The relevance of these variables to the context was also discussed with well-known research companies such as Smith Travel Research and Euromonitor International. 
Data on the performance measures and the determinants listed in Tables 1 and 2 were collected for a large sample of various hotel brands, ${ }^{3}$ distributed across 50 different tourism destinations $^{4}$. In total, a balanced sample of 2,800 observations was obtained that included 560 hotels and spanned over five years of data $(2008-2012)^{5}$. The data on the determinants were collected using a list of more than eight databases that included well-established and reliable sources such as the World Bank, World Economic Forum, Euromonitor, International, the World Travel and Tourism Council, and Smith Travel Research.

Table 5 provides a detailed explanation of the sources for data collection and a short definition of each determinant. Some variables were measured at the overall destination level (e.g., GDP and income); however, others (e.g., the performance of the overall hotel industry) were narrowed to consider a hotel's specific location. Even within one destination, some locations may perform better than others. This study focused on competing hotels operating as closely as possible to selected location of each hotel, as other studies in have shown that hotels are more impacted by nearby competition than distant competition (Baum \& Mezias, 1992; Canina, Enz, \& Harrison, 2005). Table 6 sets out the descriptive statistics of the variables included in the estimation.

\section{Results}

Before estimation, the correlation matrix (see Table 7) and the variance inflation factors (VIF) coefficients were checked to confirm that collinearity was not a problem. For each dependent variable in the data (i.e., sales per room and sales per outlet), the regression results of random effect panel data were reported. All estimations were conducted in STATA version

\footnotetext{
${ }^{3}$ The sample comprised over 249 hotel brands.

4 Table 3 lists all 50 destinations included in the study.

${ }^{5}$ We provide in Table 3 some performance indicators of major hotel brands in our sample. Note that our sample includes hotels as small as 100 rooms. So, we have a good representation of both small and large hotels.
} 
14. We also tested the random vs. the fixed effect estimators using a bootstrap Hausman test. The empirical test results show that the random effects estimator is a better fit ( $p>0.05$ for both models).

The regression results are set out in Table 8 . The first part of Table 8 reports the regression result of the sales per room model (see Model 1). The second part of Table 8 reports the regression results of sales per outlet model (see Model 2). The results for Model 1 show that the variables with significant impact on sales per room are: tax rate, GDP growth, fuel prices, disposable income, natural disasters, number of competing rooms, number of other competing accommodation providers, and the performance of the hotel industry. Other factors influencing sales per room are international tourist arrivals per capita, government expenditure, fairness of government spending, visa requirement, ease of hiring foreign labor, and quality of the educational system. Further, all these variables seem to have the expected relationship; for example, sales per room appeared to increase with higher numbers of international tourists, stronger GDP growth, and higher disposable income. Hotels also appeared to benefit from being situated in locations with high overall industry performance, easier visa entry for international tourists and more efficient government. Variables with negative effects included tax rate, higher fuel prices, and natural disasters. Being located in highly competitive areas also appeared to decrease hotel performance; for example, both the number of competing rooms and the number of other accommodation providers had a negative effect on hotel performance.

The results for Model 2 (i.e., sales per outlet) were relatively similar to the results of Model 1. Most variables had the same sign in both Models 1 and 2. However, four variables that were significant in Model 1 were insignificant in Model 2; that is, total tax rates, number of competing hotel rooms, number of natural disaster and fairness of government spending. Further, "ease of hiring of foreign labor" was significant in Model 1, but insignificant in 
Model 2. Overall, these small differences between the two models are unsurprising, as sales per room and sales per outlets measure different aspects of performance. However, as mentioned before we rely more on the results on sales per room as it is better reflection of performance, and less sensitive to size differences

Finally, Table 9 sets out the elasticity of each of the significant determinants for Models 1. This allowed the importance of each determinant to be ranked regarding its contribution to hotel performance. The determinants in Table 2 were ranked according to their percentage contribution. Variables for both models such as the fairness of government spending, international arrivals per capita, disposable income, performance of the hotel industry and quality of the educations system appeared to be the highest ranked regarding their contribution to hotel performance. Conversely, tax rate and the number of other accommodation providers appeared to be the most negatively impacting determinants. Thus, locations that were not performing well on these measures created the worst environment for hotels to grow or improve their performance.

\section{Conclusions}

Hotel strategies can directly benefit from an identification of the most important drivers affecting future performance. Several recent studies have highlighted this issue (Leonidou et al., 2013; Z. Yang \& Cai, 2016). Identifying advantage points should not be a based on instincts or anecdotal evidence, but sound science. The present study is the first large-scale study to examine the fundamental forces driving hotel performance.

Entering a new market is a resource-heavy commitment. Thus, it is paramount for hotel companies that the new location has optimal characteristics for their future performance. The present study shows that five of the six drivers identified (i.e., safety and stability, quality of infrastructure, regulation and support, market supply and demand, and labor skills 
and training) included determinants that are important facilitators or barriers to hotel performance. Only quality of infrastructure was found to be less effective in driving performance. The strongest facilitators of hotel performance were the fairness of government spending, quality of the education system, the number of international arrivals, and disposable income.

The significnat impact of government spending on hotel performance has been supported in related studies in the area (Assaf \& Josiassen, 2012; Assaf et al., 2015; Kundu \& Contractor, 1999; Marketline, 2015a; 2015b; 2015c; 2015d). The finding that education system quality was paramount to hotel performance also supports previous research (Assaf \& Agbola, 2011; Crouch \& Ritchie, 1999; Ewers, 2015; Harrington \& Akehurst, 1996; Queenan, Ferguson, \& Stratman, 2011; Sainaghi \& Baggio, 2014). Further, the number of international arrivals was found to drive hotel performance (Chen, 2007, 2010; IBISWorld, 2015; Johnson \& Vanetti, 2005; Sainaghi, 2009). Finally, a higher disposable income also appears to make it easier for hotels to improve their performance (IBISWorld, 2014, 2015; Kosova \& Enz, 2012; MarketLine, 2014; Naude \& Saayman, 2005). The effect of disposable income on hotel performance might mean that the destination has a steady and reliable source of affluent guests thus making the hotel able to be more efficient because it is less dependent on fluctuations in trends and seasonal fluctuations from overseas guests.

The factors that appear to affect hotel performance negatively are the number of other accommodation providers, the tax rate, foreign hiring, and fuel prices. Thus, hotel stakeholders looking for a new hotel location are advised to consider avoiding locations with a high number of providers already in place. Several of the managers who were interviewed noted that the threat of other accommodation providers (e.g., Airbnb) continues to negatively affect hotel performance (HVS, 2015; Zervas, Proserpio, \& Byers, 2016). Classic economics theories of demand and supply indicate that increased supply may hurt firm performance by 
depressing price to a new and lower equilibrium. The number of accommodation providers may not only be important when considering a new location, rather it is also important to monitor the competitive environment. Finally, hotel firms may wish to implement strategies for dissuading potential new entrants from entering the location by controlling the number of competitors present (Chung \& Kalnins, 2001; Pavia et al., 2014; Tavitiyaman et al., 2011). The results further show that the tax rate should be carefully considered by hotel management and policy makers. A higher tax rate turns out to be a burden to hotels which makes them less efficient (Assaf et al., 2015; Crouch \& Ritchie, 1999; Johnson \& Vanetti, 2005; MarketLine, 2015c). Rather higher tax limits the choice options for hotels and in turn their efficiency. Destinations with easy access to foreign labor are characterized by having worse performing hotels than destinations with stricter access to foreign labor. Hence, this may indicate that relying more on local and highly qualified labor seem to be a better strategy for hotels. Higher fuel prices also negatively affect hotel performance (Assaf \& Josiassen, 2012; Barros \& Dieke, 2008; MarketLine 2015c, 2015d). Higher fuel prices have some derived effects such as increased transport costs for the tourists. Hotels are advised to take into account the fuel price at the locations under consideration for the placement of a new hotel.

Figure 1 summarizes and illustrates the results graphically. The HPD framework provides valuable insight into the issues that require further investigation in this area. The framework should also facilitate discussions and communications among stakeholders involved in the management of hotel operations. Increased resource allocation efficiency is a further managerial implication of the framework, as the key drivers of hotel performance were identified and ranked. The findings can also be used to improve and inform strategic decisions, as the results remove the need of guesswork and relying on instinct. The findings of this study further advance the state of international hotel performance benchmarking. The framework can be used as a basis for auditing hotel performance. The framework also makes 
hotel international expansion choices more transparent and may be applied to ensure that economic resources are employed and investments made at those locations with the strongest performance benefits (Assaf et al., 2015; Johnson \& Vanetti, 2005).

The insights provided by these results also have societal value, as the economic optimization of market forces will benefit societies. Local government entities could use the HPD framework to identify areas of strength and weakness when developing plans to attract new hotels to the region. Tourism destinations need to continue to attract new hotels, as international hotels create jobs, increase skill levels, and increase the economic levels of the region. In addition to being able to attract hotel firms, regions must also strive to have the characteristics necessary to enable existing hotels to thrive. The framework can also be used to ascertain whether a region has the resources and characteristics necessary to ensure that hotels are attracted to the region, and their businesses can be sustained.

Future studies are encouraged to validate the HPD framework. It would also be interesting if new potential determinants were added to the framework; for example, it would be interesting to split the government spending on the tourism industry into different categories (e.g. marketing spending, infrastructure, etc.) to capture which categories of spending has the highest impact on hotel performance. It would also be interesting to conduct more detailed case studies on some specific destinations. For example, hotels located in different destinations in the same country may face different general economic conditions or may enjoy different level of government support. Finally, we believe that it would also be useful to validate these findings using a longer panel sample ${ }^{6}$.

In summary, the present paper presented the results of an international investigation of the core drivers of hotel performance in new locations. Overall, the study provided

\footnotetext{
${ }^{6}$ This can be useful to further avoid the impact of the economic crisis.
} 
important and novel insights into the theory. With careful strategy formulation, hotels could implement and monetize these insights.

\section{References}

Alegre, J. \& Cladera, M. (2006). Repeat visitation in mature sun and sand holiday destinations. Journal of Travel Research, 44(3), 288-297.

Alias, A., \& Tan, S. B. (2014). Key determinants for marketing and operational strategies of hotel business. 5(1), 1-7.

Alonso-Almeida, M. (2012). Reasons for implementing certified quality systems and impact on performance: an analysis of the hotel industry. Service Industries Journal, 32(6), 919-936.

Assaf, A. G., \& Agbola, F. W. (2011). Modelling the performance of Australian hotels: a DEA double bootstrap approach. Tourism Economics, 17(1), 73-89.

Assaf, A. G., \& Cvelbar, K. L. (2011). Privatization, market competition, international attractiveness, management tenure and hotel performance: Evidence from Slovenia. International Journal of Hospitality Management, 30(2), 391-397.

Assaf, A. G., \& Josiassen, A. (2012). Identifying and Ranking the Determinants of Tourism Performance: A Global Investigation. Journal of Travel Research, 51(4), 388-399.

Assaf, A. G., \& Josiassen, A. (2015). Frontier Analysis: A State-of-the-Art Review and MetaAnalysis. Journal of Travel Research, 17, 1-16.

Assaf, A. G., Josiassen, A., \& Agbola, F. W. (2015). Attracting international hotels: Locational factors that matter most. Tourism Management, 47, 329-340.

Assaf, A. G., Josiassen, A., \& Cvelbar, L. K. (2012). Does triple bottom line reporting improve hotel performance? International Journal of Hospitality Management, 31(2), 596-600. 
Awang, K. W., Ishak, N. K., Mohd Radzi, S., \& Taha, A. Z. (2008). Environmental Variables and Performance: Evidence from the Hotel Industry in Malaysia. International Journal of Economics and Management, 2(1), 59-79.

Barros, C. P., \& Dieke, P. U. C. (2008). Technical efficiency of African hotels. International Journal of Hospitality Management, 27(3), 438-447.

Baum, J. A. C., \& Mezias, S. J. (1992). Localized competition and organizational failure in the Manhattan hotel industry, 1898-1990. Administrative Science Quarterly, 37(4), $580-604$.

Beerli, A., \& Martín, J. D. (2004). Tourists' characteristics and the perceived image of tourist destinations: A quantitative analysis - A case study of Lanzarote, Spain. Tourism Management, 25(5), 623-636.

Bolat, T., \& Yilmaz, Ö. (2009). The relationship between outsourcing and organizational performance: Is it myth or reality for the hotel sector? International Journal of Contemporary Hospitality Management, 21(1), 7-23.

Briassoulis, H. (2002). Sustainable tourism and the question of the commons. Annals of Tourism Research, 29(4), 1065-1085.

Canina, L., Enz, C. A., \& Harrison, J. S. (2005). Agglomeration Effects and Strategic Orientations: Evidence From the U.S., 48(4), 565-581.

Chen, M. H. (2007). Macro and non-macro explanatory factors of Chinese hotel stock returns. International Journal of Hospitality Management, 26(4), 991-1004.

Chen, M. H. (2010). The economy, tourism growth and corporate performance in the Taiwanese hotel industry. Tourism Management, 31(5), 665-675.

Chen, M. H., Jang, S. (Shawn), \& Kim, W. G. (2007). The impact of the SARS outbreak on Taiwanese hotel stock performance: An event-study approach. International Journal of Hospitality Management, 26(1), 200-212. 
Chen, M. H., Kim, W. G., \& Kim, H. J. (2005). The impact of macroeconomic and nonmacroeconomic forces on hotel stock returns. International Journal of Hospitality Management, 24(2), 243-258.

Cho, S., Woods, R. H., Jang, S., \& Erdem, M. (2006). Measuring the impact of human resource management practices on hospitality firms' performances. International Journal of Hospitality Management, 25(2), 262-277.

Chung, W., \& Kalnins, A. (2001). Agglomeration effects and performance: A test of the Texas lodging industry. Strategic Management Journal, 22(10), 969-988.

Creswell, J. W. (2009). Research design: Qualitative, quantitative, and mixed methods approaches (3rd ed.). Thousand Oaks, CA: Sage Publications.

Crouch, G. I., \& Ritchie, J. R. B. (1999). Tourism, Competitiveness, and Societal Prosperity. Journal of Business Research, 44(3), 137-152.

Ewers, M. C. (2015). Oil, human capital and diversification: the challenge of transition in the UAE and the Arab Gulf States. The Geographical Journal, n/a-n/a.

Faulkner, B., Oppermann, M., \& Fredline, E. (1999). Destination competitiveness: An exploratory examination of South Australia's core attractions. Journal of Vacation Marketing, 5(2), 125-139.

George, R. (2003). Tourist's perceptions of safety and security while visiting Cape Town. Tourism Management, 24(5), 575-585.

Harper, D. W. (2001). Comparing Tourists Crime Victimization. Annals of Tourism Research, 28(4), 1053-1056.

Harrington, D., \& Akehurst, G. (1996). Service quality and business performance in the UK hotel industry. International Journal of Hospitality Management, 15(3), 283-298.

HVS. (2015). Impact Analysis Report: Airbnb and Impacts on the New York City Lodging Market and Economy. Retrieved from www.hvs.com 
IBISWorld. (2014). IBISWorld Industry Report: Global Hotels \& Resorts. Retrieved from www.ibisworld.com

IBISWorld. (2015). IBISWorld Industry Report 72111: Hotels \& Motels in the US. IBISWorld Inc. Retrieved from www.ibisworld.com

Jogaratnam, G., \& Tse, E. C.-Y. (2006). Entrepreneurial orientation and the structuring of organizations: Performance evidence from the Asian hotel industry. International Journal of Contemporary Hospitality Management, 18(6), 454-468.

Johnson, C., \& Vanetti, M. (2005). Locational strategies of international hotel chains. Annals of Tourism Research, 32(4), 1077-1099.

Kamasivayan, K., Enz, C. A., \& Siguaw, J. A. (2001). How wired are we? Selection and use of new technology in US hotels. The Cornell Hotel and Restaurant Administration Quarterly, 41, 40-48.

Karadag, E., Cobanoglu, C., \& Dickinson, C. (2009). The characteristics of IT investment decisions and methods used in the US lodging industry. International Journal of Contemporary Hospitality Management, 21(1), 52-68.

Kim, W. G., \& Brymer, R. A. (2011). The effects of ethical leadership on manager job satisfaction, commitment, behavioral outcomes, and firm performance. International Journal of Hospitality Management, 30(4), 1020-1026.

Kosova, R., \& Enz, C. a. (2012). The Terrorist Attacks of 9/11 and the Financial Crisis of 2008: The Impact of External Shocks on U.S. Hotel Performance. Cornell Hospitality Quarterly, 53, 308-325.

Lee, S., \& Park, S. Y. (2009). Do socially responsible activities help hotels and casinos achieve their financial goals? International Journal of Hospitality Management, 28(1), $105-112$. 
Leonidou, L. C., Leonidou, C. N., Fotiadis, T. A., \& Zeriti, A. (2013). Resources and capabilities as drivers of hotel environmental marketing strategy: Implications for competitive advantage and performance. Tourism Management, 35, 94-110.

MarketLine. (2014). COMPANY PROFILE: Hyatt Hotels Corporation. Retrieved from www.marketline.com

MarketLine. (2015a). COMPANY PROFILE: Hilton Worldwide Holdings Inc. Retrieved from www.marketline.com

MarketLine. (2015b). COMPANY PROFILE: InterContinental Hotels Group Plc. Retrieved from www.marketline.com

MarketLine. (2015c). COMPANY PROFILE: Marriott International, Inc. Retrieved from www.marketline.com

MarketLine. (2015d). COMPANY PROFILE: Starwood Hotels \& Resorts Worldwide, Inc. Retrieved from www.marketline.com

Namasivayam, K., Miao, L., \& Zhao, X. (2007). An investigation of the relationships between compensation practices and firm performance in the US hotel industry. International Journal of Hospitality Management, 26(3), 574-587.

Naude, W. A., \& Saayman, A. (2005). Determinants of tourist arrivals in Africa : Tourism Economics, 11(3), 365-391.

O’Neill, J. W., \& Mattila, A. S. (2006). Strategic hotel development and positioning: The effects of revenue drivers on profitability. Cornell Hotel and Restaurant Administration Quarterly, 47(2), 146-154.

Oliveira, R., Pedro, M. I., \& Marques, R. C. (2013). Efficiency and its determinants in Portuguese hotels in the Algarve. Tourism Management, 36, 641-649. 
Pavia, N., Gržinić, J., \& Floričić, T. (2014). Specialisation as a trend in modern hotel industry. Faculty of Tourism and Hospitality Management in Opatija. Biennial International Congress. Tourism and Hospitality Industry, 256-272.

Peiró-Signes, A., Segarra-Oña, M.-V., Miret-Pastor, L., \& Verma, R. (2015). The effect of tourism clusters on US hotel performance. Cornell Hospitality Quarterly, 56(2), 155167.

Queenan, C. C., Ferguson, M. E., \& Stratman, J. K. (2011). Revenue management performance drivers: An exploratory analysis within the hotel industry. Journal of Revenue and Pricing Management, 10(2), 172-188.

Sainaghi, R. (2009). Determinants of hotel performance: research styles. In 2009 TTRA Annual Conference Proceedings Determinants, 153-163.

Sainaghi, R. (2010). Hotel performance: state of the art. International Journal of Contemporary Hospitality Management, 22(7), 920-952.

Sainaghi, R. (2011). RevPAR determinants of individual hotels: Evidences from Milan. International Journal of Contemporary Hospitality Management, 23(3), 297-311.

Sainaghi, R., \& Baggio, R. (2014). Structural social capital and hotel performance: Is there a link? International Journal of Hospitality Management, 37, 99-110.

Shaw, G., \& Williams, A. (2009). Knowledge transfer and management in tourism organisations: An emerging research agenda. Tourism Management, 30(3), 325-335.

Siguaw, J. A., Enz, C. A., \& Namasivayam, K. (2000). Adoption of information technology in US hotels: Strategically driven objectives. Journal of Travel Research, 39(November), 192-201.

Sirirak, S., Islam, N., \& Khang, D. B. (2011). Does ICT adoption enhance hotel performance? Journal of Hospitality and Tourism Technology, 2(1), 34-49. 
Srnka, K. J., \& Koeszegi, S. T. (2007). From words to numbers: How to transform qualitative data into meaningful quantitative results. Schmalenbach Business Review, 59(1), 2957.

Sun, L.-Y., Aryee, S., \& Law, K. S. (2007). High-performance human resource practices, citizenship behavior, and organizational performance: A relational perspective. Academy of Management Journal, 50(3), 558-577.

Tavitiyaman, P., Qu, H., \& Zhang, H. Q. (2011). The impact of industry force factors on resource competitive strategies and hotel performance. International Journal of Hospitality Management, 30(3), 648-657.

Wang, C.-H., Chen, K.-Y., \& Chen, S.-C. (2012). Total quality management, market orientation and hotel performance: The moderating effects of external environmental factors. International Journal of Hospitality Management, 31(1), 119-129.

Weber, R. (2004). The rhetoric of positivism versus interpretivism: A personal view. MIS Quarterly, 28(1), 3-12.

Yang, Y., Wong, K. K. F., \& Wang, T. (2012). How do hotels choose their location? Evidence from hotels in Beijing. International Journal of Hospitality Management, $31(3), 675-685$.

Yang, Z., \& Cai, J. (2016). Do regional factors matter? Determinants of hotel industry performance in China. Tourism Management, 52(January 2014), 242-253.

Yeung, P. K., \& Lau, C. M. (2005). Competitive actions and firm performance of hotels in Hong Kong. International Journal of Hospitality Management, 24(4), 611-633.

Zervas, G., Proserpio, D., \& Byers, J. (2016). The Rise of the Sharing Economy: Estimating the Impact of Airbnb on the Hotel Industry. Boston U. School of Management Research Paper, 1-36.

Zheng, T. (2014). What caused the decrease in RevPAR during the recession? An ARIMA 
with intervention analysis of room supply and market demand. International Journal of Contemporary Hospitality Management, 26(8), 1225-1242.

Zhou, K. Z., Brown, J. R., \& Dev, C. S. (2009). Market orientation, competitive advantage, and performance: A demand-based perspective. Journal of Business Research, 62(11), 1063-1070. 
Table 1. Variables identified from the literature and industry interviews

\begin{tabular}{|c|c|c|}
\hline & Literature & $\begin{array}{l}\text { Identified by } \\
\text { Interview } \\
\text { Participants }\end{array}$ \\
\hline Tax rate & $\begin{array}{l}\text { (Assaf, Josiassen, \& Agbola, 2015; Crouch \& } \\
\text { Ritchie, 1999; IBISWorld, 2014; Johnson \& } \\
\text { Vanetti, 2005) }\end{array}$ & Yes \\
\hline $\begin{array}{l}\text { Gross Domestic } \\
\text { Product growth }\end{array}$ & $\begin{array}{l}\text { (Chen, 2007, 2010; Chen, Kim, \& Kim, } \\
\text { 2005; IBISWorld, 2014; Kosova \& Enz, } \\
\text { 2012; Naude \& Saayman, 2005) }\end{array}$ & Yes \\
\hline Exchange rate & $\begin{array}{l}\text { (Assaf \& Josiassen, 2012; Assaf et al., 2015; } \\
\text { Crouch \& Ritchie, 1999; IBISWorld, 2014; } \\
\text { Naude \& Saayman, 2005) }\end{array}$ & Yes \\
\hline Fuel prices & $\begin{array}{l}\text { (Assaf \& Josiassen, 2012; Crouch \& Ritchie, } \\
\text { 1999; Ewers, 2015) }\end{array}$ & Yes \\
\hline Disposable income & $\begin{array}{l}\text { (Chen et al., 2005; IBISWorld, 2014, 2015; } \\
\text { Kosova \& Enz, 2012; Naude \& Saayman, } \\
\text { 2005) }\end{array}$ & Yes \\
\hline $\begin{array}{l}\text { Number of natural } \\
\text { disasters }\end{array}$ & $\begin{array}{l}\text { (Chen, 2007, 2010; Chen et al., 2005; 2007; } \\
\text { Crouch \& Ritchie, 1999; Kaplan \& Norton, } \\
\text { 2000; Sainaghi, 2010) }\end{array}$ & Yes \\
\hline Crime rate & $\begin{array}{l}\text { (Assaf \& Josiassen, 2012; Assaf et al., 2015; } \\
\text { Beerli \& Martín, 2004; Chen, 2007, 2010; } \\
\text { Chen et al., 2005; Crouch \& Ritchie, 1999; } \\
\text { George, 2003; Harper, 2001; IBISWorld, } \\
\text { 2015, 2014; Kosova \& Enz, 2012; Sainaghi, } \\
\text { 2010; Zheng, 2014) }\end{array}$ & Yes \\
\hline $\begin{array}{l}\text { Number of other } \\
\text { accommodation } \\
\text { providers }\end{array}$ & $\begin{array}{l}\text { (HVS, 2015; IBISWorld, 2015; Zervas et al., } \\
\text { 2016) }\end{array}$ & Yes \\
\hline $\begin{array}{l}\text { Number of } \\
\text { competing hotel } \\
\text { rooms }\end{array}$ & $\begin{array}{l}\text { (Baum \& Mezias, 1992; Chung \& Kalnins, } \\
\text { 2001; Kosova \& Enz, 2012; Naude \& } \\
\text { Saayman, 2005; Yang \& Cai, 2016; Zheng, } \\
\text { 2014) }\end{array}$ & Yes \\
\hline $\begin{array}{l}\text { Performance of the } \\
\text { overall hotel } \\
\text { industry }\end{array}$ & $\begin{array}{l}\text { (Assaf \& Cvelbar, 2011; Assaf \& Josiassen, } \\
\text { 2012; 2015; Canina et al., 2005; Chung \& } \\
\text { Kalnins, 2001; O'Neill \& Mattila, 2006; } \\
\text { Pavia, et al., 2014; Peiro-Signes et al., 2014; } \\
\text { Wang et al., 2012; Yang \& Cai, 2016; Yang } \\
\text { et al., 2012) }\end{array}$ & Yes \\
\hline Domestic tourist & (Assaf \& Josiassen, 2012; Awang et al., & Yes \\
\hline
\end{tabular}




\begin{tabular}{|c|c|c|}
\hline arrivals per capita & $\begin{array}{l}\text { 2008; IBISWorld, 2014, 2015; Naude \& } \\
\text { Saayman, 2005; Oliveira et al., 2013; Yang et } \\
\text { al., 2012) }\end{array}$ & \\
\hline $\begin{array}{l}\text { International tourist } \\
\text { arrivals per capita }\end{array}$ & $\begin{array}{l}\text { ( Awang et al., 2008; Chen, 2007, 2010; } \\
\text { Chen et al., 2005; Crouch \& Ritchie, 1999; } \\
\text { IBISWorld, 2015; Jogaratnam \& Tse, 2006; } \\
\text { Naude \& Saayman, 2005) }\end{array}$ & Yes \\
\hline $\begin{array}{l}\text { T\&T government } \\
\text { expenditure }\end{array}$ & $\begin{array}{l}\text { (Assaf \& Josiassen, 2012, Assaf et al., 2015; } \\
\text { Briassoulis, 2002; Chen, 2010; Crouch \& } \\
\text { Ritchie, 1999) }\end{array}$ & Yes \\
\hline $\begin{array}{l}\text { Transparency of } \\
\text { government policies }\end{array}$ & $\begin{array}{l}\text { (Barros \& Dieke, 2008; Bolat \& Yilmaz, } \\
\text { 2009; Chen, 2007; 2010; Crouch \& Ritchie, } \\
\text { 1999; Leonidou et al. 2013; Yang \& Cai, } \\
\text { 2016; Yang et al., 2012) }\end{array}$ & Yes \\
\hline $\begin{array}{l}\text { Fairness in } \\
\text { government } \\
\text { spending }\end{array}$ & $\begin{array}{l}\text { (Assaf \& Cvelbar, 2011; Assaf \& Josiassen, } \\
\text { 2012, Assaf et al., 2015; Awang et al., 2008; } \\
\text { Briassoulis, 2002; Crouch \& Ritchie, 1999; } \\
\text { Leonidou et al. 2013; Yang \& Cai, 2016) }\end{array}$ & Yes \\
\hline Visa policies & $\begin{array}{l}\text { (Assaf \& Josiassen, 2012; Crouch \& Ritchie, } \\
1999 \text { ) }\end{array}$ & No \\
\hline $\begin{array}{l}\text { Quality of air } \\
\text { transport } \\
\text { infrastructure }\end{array}$ & $\begin{array}{l}\text { (Assaf et al., 2015; Crouch \& Ritchie, 1999; } \\
\text { Kosova \& Enz, 2012; Naude \& Saayman, } \\
\text { 2005; Yang \& Cai, 2016; Yang et al., 2012) }\end{array}$ & Yes \\
\hline $\begin{array}{l}\text { Quality of port } \\
\text { infrastructure }\end{array}$ & $\begin{array}{l}\text { (Assaf \& Josiassen, 2012; Beerli \& Martin, } \\
\text { 2004; Briassoulis, 2002) }\end{array}$ & Yes \\
\hline $\begin{array}{l}\text { Quality of road } \\
\text { infrastructure }\end{array}$ & $\begin{array}{l}\text { (Assaf \& Josiassen, 2012; Assaf et al., 2015; } \\
\text { Beerli \& Martin, 2004; Briassoulis, 2002; } \\
\text { Crouch \& Ritchie, 1999; Naude \& Saayman, } \\
\text { 2005; Yang et al., 2012) }\end{array}$ & Yes \\
\hline $\begin{array}{l}\text { Ease of hiring of } \\
\text { foreign labor }\end{array}$ & $\begin{array}{l}\text { (Assaf et al., 2015; Ewers, 2015; Yang \& } \\
\text { Cai, 2016) }\end{array}$ & No \\
\hline $\begin{array}{l}\text { Quality of the } \\
\text { education system }\end{array}$ & $\begin{array}{l}\text { (Assaf \& Josiassen, 2012; Assaf et al., 2015; } \\
\text { Bolat \& Yilmaz, 2009; Crouch \& Ritchie, } \\
\text { 1999; Ewers, 2015; Harrington \& Akehurst, } \\
\text { 1996; IBISWorld, 2014; Sainaghi \& Baggio, } \\
\text { 2014; Sirirak et al., 2011; Sun et al., 2007; } \\
\text { Tavitiyaman et al., 2011; Yang \& Cai, 2016) }\end{array}$ & Yes \\
\hline
\end{tabular}


Table 2

Determinants of Hotel Performance

\section{$1^{\text {st }}$ General Economic Conditions}

1.1. Tax rate

1.2. Gross Domestic Product growth

1.3. Exchange rate

1.4. Fuel price

1.5. Disposable income

\section{$2^{\text {nd }}$ Safety and Stability}

2.1. Number of natural disasters

2.2. Crime rate

\section{$3^{\text {rd }}$ Market Supply and Demand}

3.1. Number of other accommodation providers

3.2. Number of competing hotel rooms

3.3. Performance of the overall hotel industry

3.4. Domestic tourist arrivals per capita

3.5. International tourist arrivals per capita $4^{\text {th }}$ Regulation and Support

4.1. T\&T government expenditure

4.2. Transparency of government policies

4.3. Fairness in government spending

4.4. Visa Requirements

$5^{\text {th }}$ Quality of Infrastructure

5.1. Quality of air transport infrastructure

5.2. Quality of port infrastructure

5.3. Quality of road infrastructure

$6^{\text {th }}$ Labor Skills and Training

6.1. Ease of hiring of foreign labor

6.2. Quality of the education system 
Table 3. List of Destinations Covered in the Study

Austria, Belgium, Brazil, Bulgaria, Canada, Chile, China, Colombia, Croatia, Czech Republic, Denmark, Ecuador, Egypt, Finland, France, Germany, Greece, Hong Kong, Hungary, India, Indonesia, Ireland, Israel, Italy, Japan, Malaysia, Mexico, Morocco, Netherlands, Norway, Peru, Philippines, Poland, Portugal, Romania, Russia, Saudi Arabia, Slovakia, Slovenia, South Africa, South Korea, Spain, Sweden, Switzerland, Thailand, Turkey, United Arab Emirates, United Kingdom, USA, Vietnam 
Table 4

Performance indicators of some major hotel brands in our samples

\begin{tabular}{|c|c|c|c|}
\hline \multirow[t]{2}{*}{ Brand (Company) } & \multirow[t]{2}{*}{ Year } & $\begin{array}{l}\text { Sales Per } \\
\text { Room }\end{array}$ & $\begin{array}{c}\text { Sales per } \\
\text { outlet }\end{array}$ \\
\hline & & Mean & Mean \\
\hline \multirow{5}{*}{$\begin{array}{c}\text { Mercure } \\
\text { (Accor Group) }\end{array}$} & 2008 & 28.56 & 3.38 \\
\hline & 2009 & 24.93 & 2.97 \\
\hline & 2010 & 25.15 & 3.01 \\
\hline & 2011 & 26.90 & 3.26 \\
\hline & 2012 & 24.42 & 2.99 \\
\hline \multirow{5}{*}{$\begin{array}{c}\text { Sheraton Hotel } \\
\text { (Starwood Hotels \& Resorts) }\end{array}$} & 2008 & 37.47 & 13.98 \\
\hline & 2009 & 31.62 & 11.95 \\
\hline & 2010 & 36.61 & 13.00 \\
\hline & 2011 & 39.62 & 13.78 \\
\hline & 2012 & 41.39 & 14.28 \\
\hline \multirow{5}{*}{$\begin{array}{c}\text { Crowne Plaza } \\
\text { (InterContinental Hotels Group) }\end{array}$} & 2008 & 36.02 & 10.19 \\
\hline & 2009 & 30.71 & 8.73 \\
\hline & 2010 & 32.18 & 9.15 \\
\hline & 2011 & 31.75 & 9.01 \\
\hline & 2012 & 31.86 & 8.90 \\
\hline \multirow{5}{*}{$\begin{array}{c}\text { Shangri-La } \\
\text { (Shangri-La Hotel \& Resort) }\end{array}$} & 2008 & 47.29 & 22.24 \\
\hline & 2009 & 43.32 & 18.68 \\
\hline & 2010 & 45.20 & 19.34 \\
\hline & 2011 & 50.54 & 22.44 \\
\hline & 2012 & 55.95 & 25.04 \\
\hline \multirow{5}{*}{$\begin{array}{c}\text { InterContinental } \\
\text { (InterContinental Hotels Group) }\end{array}$} & 2008 & 52.06 & 19.63 \\
\hline & 2009 & 42.44 & 15.46 \\
\hline & 2010 & 41.86 & 15.43 \\
\hline & 2011 & 42.64 & 15.71 \\
\hline & 2012 & 42.96 & 15.74 \\
\hline \multirow{5}{*}{$\begin{array}{c}\text { Sofitel } \\
\text { (Accor Group) }\end{array}$} & 2008 & 53.16 & 14.39 \\
\hline & 2009 & 45.76 & 13.00 \\
\hline & 2010 & 45.13 & 13.13 \\
\hline & 2011 & 51.31 & 14.74 \\
\hline & 2012 & 48.79 & 13.37 \\
\hline \multirow{5}{*}{$\begin{array}{c}\text { Ritz-Carlton } \\
\text { (Marriott International) }\end{array}$} & 2008 & 88.41 & 27.45 \\
\hline & 2009 & 70.13 & 21.41 \\
\hline & 2010 & 76.02 & 22.85 \\
\hline & 2011 & 82.06 & 24.64 \\
\hline & 2012 & 86.38 & 25.58 \\
\hline
\end{tabular}


Table 5

Variables and Measures

\begin{tabular}{|c|c|c|c|}
\hline & Determinant & Description & Sources of Data \\
\hline 1.1. & Tax rate & $\begin{array}{l}\text { The amount of taxes and mandatory } \\
\text { contributions borne by the business in the } \\
\text { second year of operation. }\end{array}$ & $\begin{array}{l}\text { Doing Business Project- } \\
\text { World Bank }\end{array}$ \\
\hline 1.2. & $\begin{array}{l}\text { Gross Domestic } \\
\text { Product growth }\end{array}$ & $\begin{array}{l}\text { The real Gross Domestic Product growth } \\
\text { rate in the country in a specific year. }\end{array}$ & $\begin{array}{l}\text { OECD/UN/International } \\
\text { Monetary Fund, World } \\
\text { Economic Outlook }\end{array}$ \\
\hline 1.3. & Exchange rate & Exchange rate against the U.S. dollar. & $\begin{array}{l}\text { International Monetary } \\
\text { Fund }\end{array}$ \\
\hline 1.4. 1 & Fuel price & $\begin{array}{l}\text { Pump price for the grade of gasoline } \\
\text { (U.S. dollars per liter) sold (averaged over } \\
\text { the two years preceding each year). }\end{array}$ & $\begin{array}{l}\text { German Agency for } \\
\text { International Cooperation } \\
(\text { GIZ) }\end{array}$ \\
\hline 1.5. & $\begin{array}{l}\text { Disposable } \\
\text { income }\end{array}$ & $\begin{array}{l}\text { Annual disposal income (U.S. dollars). } \\
\text { Measured as gross income minus social } \\
\text { security contributions and income taxes. }\end{array}$ & Euromonitor International \\
\hline 2.1 & $\begin{array}{l}\text { Number of } \\
\text { natural disaster }\end{array}$ & $\begin{array}{l}\text { The number of natural disasters in the } \\
\text { country in a specific year. }\end{array}$ & $\begin{array}{l}\text { Centre for Research on the } \\
\text { Epidemiology of Disasters }\end{array}$ \\
\hline 2.2. & Crime rate & $\begin{array}{l}\text { The burden of business expenses } \\
\text { occasioned by the organized crime (e.g., } \\
\text { mafia-oriented racketeering and } \\
\text { extortion) measured as an index from } 1 \text { to } \\
7 \text { (where } 1=\text { to a great extent and } 7=\text { not } \\
\text { at all). }\end{array}$ & World Economic Forum \\
\hline 3.1. & $\begin{array}{l}\text { Number of other } \\
\text { accommodation } \\
\text { providers }\end{array}$ & $\begin{array}{l}\text { The number of other types of } \\
\text { accommodation (e.g., campsites, hostels, } \\
\text { private rentals, self-catering apartments, } \\
\text { chalets and motels, inns) in the country. }\end{array}$ & Euromonitor International \\
\hline 3.2. & $\begin{array}{l}\text { Number of } \\
\text { competing hotel } \\
\text { rooms }\end{array}$ & $\begin{array}{l}\text { The sum of hotels' rooms at the tract } \\
\text { (sub-market) level of main destinations in } \\
\text { a country. The tract is a geographic subset } \\
\text { of a metropolitan statistical area (as } \\
\text { defined by Smith Travel Research } \\
\text { (STR)). Only hotels in the tract markets } \\
\text { are included in this variable. }\end{array}$ & Smith Travel Research \\
\hline
\end{tabular}




\begin{tabular}{|c|c|c|c|}
\hline 3.3. & $\begin{array}{l}\text { Performance of } \\
\text { the overall hotel } \\
\text { industry }\end{array}$ & $\begin{array}{l}\text { The average of hotels' performance at the } \\
\text { tract (sub-market) level of main } \\
\text { destinations in the country. RevPAR is } \\
\text { used as hotel performance measurement. } \\
\text { The tract is a geographic subset of a } \\
\text { metropolitan statistical area and defined } \\
\text { by Smith Travel Research (STR). Only } \\
\text { hotels in the tract markets are included in } \\
\text { this variable. }\end{array}$ & $\begin{array}{l}\text { Smith Travel Research, } \\
\text { Euromonitor International }\end{array}$ \\
\hline 3.4. & $\begin{array}{l}\text { Domestic tourist } \\
\text { arrivals per } \\
\text { capita }\end{array}$ & $\begin{array}{l}\text { The number of domestic trips divided by } \\
\text { population in the country in a specific } \\
\text { year. Domestic trips refer to trips taken by } \\
\text { residents of the country within their } \\
\text { country of residence. Day trips are } \\
\text { excluded in this variable. }\end{array}$ & Euromonitor International \\
\hline 3.5. & $\begin{array}{l}\text { International } \\
\text { tourist arrivals } \\
\text { per capita }\end{array}$ & $\begin{array}{l}\text { Arrivals taken by international tourists } \\
\text { divided by population in the country in a } \\
\text { specific year. International tourists are } \\
\text { defined as visitors from another country } \\
\text { for a period of at least } 24 \text { hours, but not } \\
\text { more than } 12 \text { months, and may stay for } \\
\text { various purposes (e.g., leisure, business, } \\
\text { visiting friends and family, religious, } \\
\text { medical). }\end{array}$ & Euromonitor International \\
\hline 4.1. & $\begin{array}{l}\text { T\&T government } \\
\text { expenditure }\end{array}$ & $\begin{array}{l}\text { The percentage of the total budget made } \\
\text { by government agencies to provide travel } \\
\text { and tourism services (e.g., art museums, } \\
\text { national parks and immigration/customs) } \\
\text { to visitors. }\end{array}$ & $\begin{array}{l}\text { World Travel and Tourism } \\
\text { Council }\end{array}$ \\
\hline 4.2. & $\begin{array}{l}\text { Transparency of } \\
\text { government } \\
\text { policies }\end{array}$ & $\begin{array}{l}\text { The extent of governments' favoritism to } \\
\text { well-connected firms when deciding their } \\
\text { policies measured as an index from } 1 \text { to } 7 \\
\text { (where } 1=\text { always show favoritism and } 7 \\
=\text { never show favoritism). }\end{array}$ & World Economic Forum \\
\hline 4.3. & $\begin{array}{l}\text { Fairness in } \\
\text { government } \\
\text { spending }\end{array}$ & $\begin{array}{l}\text { Government expenditure efficiency in } \\
\text { providing goods and services measured as } \\
\text { an index from } 1 \text { to } 7 \text { (where } 1= \\
\text { extremely inefficient and } 7=\text { extremely } \\
\text { efficient). }\end{array}$ & World Economic Forum \\
\hline 4.4. & $\begin{array}{l}\text { Visa } \\
\text { Requirement }\end{array}$ & $\begin{array}{l}\text { The weighted sum of } U N \text { countries whose } \\
\text { citizens require a visa to enter the country } \\
\text { (where visa exemption }=1 \text {, possibility of } \\
\text { electronic visa }=0.5 \text {, upon arrival }=0.7 \text { ) }\end{array}$ & $\begin{array}{l}\text { World Tourism } \\
\text { Organization }\end{array}$ \\
\hline
\end{tabular}




\begin{tabular}{|l|l|l|l|}
\hline 5.1. & $\begin{array}{l}\text { Quality of air } \\
\text { transport } \\
\text { infrastructure }\end{array}$ & $\begin{array}{l}\text { Perceived quality of air transport } \\
\text { infrastructure in the country measured as } \\
\text { an index from 1 to 7 (where 1 } \\
\text { extremely underdeveloped and 7 } \\
\text { extensive and efficient). }\end{array}$ & World Economic Forum \\
\hline 5.2. & $\begin{array}{l}\text { Quality of port } \\
\text { infrastructure }\end{array}$ & $\begin{array}{l}\text { Perceived quality of seaports in the } \\
\text { country measured as an index from 1 to 7 } \\
\text { (where 1 extremely underdeveloped and } \\
7=\text { extensive and efficient) }\end{array}$ & World Economic Forum \\
\hline 5.3. & $\begin{array}{l}\text { Quality of road } \\
\text { infrastructure }\end{array}$ & $\begin{array}{l}\text { Perceived quality of roads in the country } \\
\text { measured as an index from 1 to 7 (where } \\
1=\text { extremely underdeveloped and 7 = } \\
\text { extensive and efficient). }\end{array}$ & World Economic Forum \\
\hline 6.1. & $\begin{array}{l}\text { Ease of hiring } \\
\text { foreign labor }\end{array}$ & $\begin{array}{l}\text { The extent of openness of hiring foreign } \\
\text { labors measured as an index from 1 to 7 } \\
\text { (where 1 = very much limits and 7 = does } \\
\text { not limit at all). }\end{array}$ & World Economic Forum \\
\hline 6.2. & $\begin{array}{l}\text { Quality of the } \\
\text { educational } \\
\text { system }\end{array}$ & $\begin{array}{l}\text { Perceived quality of business schools in } \\
\text { the country measured as an index from 1 } \\
\text { to 7 (where 1 = extremely poor and 7 } \\
=\text { excellent) }\end{array}$ & World Economic Forum \\
\hline
\end{tabular}


Table 6

Descriptive Statistics of all Model Variables

\begin{tabular}{|c|c|c|}
\hline Variable & Mean & Std. dev \\
\hline Sales per room & 42.85 & 44.47 \\
\hline Sales per outlet & 10.54 & 12.89 \\
\hline Tax rate & 43.96 & 14.45 \\
\hline Gross Domestic Product growth & 2.17 & 3.92 \\
\hline Exchange rate & 724.94 & 3,103 \\
\hline Fuel price & 1.35 & 0.50 \\
\hline Disposable income & $1,713,960$ & $3,011,398$ \\
\hline Number of natural disaster & 5.97 & 7.80 \\
\hline Crime rate & 5.34 & 0.90 \\
\hline Number of other accommodation providers & 4.44 & 0.82 \\
\hline Number of competing hotel rooms & $6,061.95$ & $17,144.96$ \\
\hline Performance of the overall hotel industry & 96.27 & 103.35 \\
\hline Domestic tourist arrivals per capita & 2.49 & 8.44 \\
\hline International tourist arrivals per capita & 0.56 & 0.63 \\
\hline T\&T government expenditure & 3.87 & 2.18 \\
\hline Transparency of government policies & 3.65 & 0.85 \\
\hline Fairness in government spending & 3.58 & 0.82 \\
\hline Visa policies & 62.18 & 29.72 \\
\hline Quality of air transport infrastructure & 5.42 & 0.89 \\
\hline Quality of port infrastructure & 4.84 & 1.07 \\
\hline Quality of road infrastructure & 4.90 & 1.29 \\
\hline Ease of hiring foreign labor & 4.49 & 0.66 \\
\hline Quality of the education system & 4.83 & 0.77 \\
\hline
\end{tabular}


Table 7

Correlation Matrix for All Model Variables

\begin{tabular}{|c|c|c|c|c|c|c|c|c|c|c|c|c|c|c|c|c|c|c|c|c|c|}
\hline & 1 & 2 & 3 & 4 & 5 & 6 & 7 & 8 & 9 & 10 & 11 & 12 & 13 & 14 & 15 & 16 & 17 & 18 & 19 & 20 & 21 \\
\hline 1 & 1 & & & & & & & & & & & & & & & & & & & & \\
\hline 2 & 0.14 & 1 & & & & & & & & & & & & & & & & & & & \\
\hline 3 & -0.11 & 0.20 & 1 & & & & & & & & & & & & & & & & & & \\
\hline 4 & 0.05 & -0.19 & -0.23 & 1 & & & & & & & & & & & & & & & & & \\
\hline 5 & 0.22 & -0.02 & -0.11 & -0.31 & 1 & & & & & & & & & & & & & & & & \\
\hline 6 & 0.47 & 0.37 & 0.08 & -0.41 & 0.69 & 1 & & & & & & & & & & & & & & & \\
\hline 7 & -0.37 & -0.20 & -0.14 & 0.25 & -0.13 & -0.33 & 1 & & & & & & & & & & & & & & \\
\hline 8 & 0.39 & -0.14 & -0.40 & -0.06 & 0.73 & 0.49 & 0.01 & 1 & & & & & & & & & & & & & \\
\hline 9 & 0.10 & -0.04 & -0.07 & -0.19 & 0.62 & 0.41 & -0.05 & 0.46 & 1 & & & & & & & & & & & & \\
\hline 10 & -0.33 & -0.07 & -0.03 & 0.06 & -0.18 & -0.23 & 0.03 & -0.13 & -0.10 & 1 & & & & & & & & & & & \\
\hline 11 & 0.11 & 0.30 & 0.15 & -0.14 & -0.02 & 0.26 & -0.00 & -0.12 & -0.03 & -0.10 & 1 & & & & & & & & & & \\
\hline 12 & -0.31 & -0.33 & -0.19 & 0.39 & -0.27 & -0.45 & 0.48 & -0.13 & -0.13 & 0.28 & -0.20 & 1 & & & & & & & & & \\
\hline 13 & -0.11 & -0.13 & 0.05 & -0.17 & 0.13 & 0.13 & 0.14 & 0.02 & 0.10 & -0.14 & -0.10 & 0.28 & 1 & & & & & & & & \\
\hline 14 & -0.27 & -0.10 & -0.09 & 0.09 & -0.04 & -0.19 & 0.68 & 0.01 & -0.02 & -0.09 & 0.03 & 0.24 & 0.13 & 1 & & & & & & & \\
\hline 15 & -0.42 & 0.11 & -0.06 & -0.15 & -0.12 & -0.11 & 0.56 & -0.17 & -0.06 & -0.06 & 0.12 & 0.24 & 0.15 & 0.79 & 1 & & & & & & \\
\hline 16 & -0.28 & -0.11 & 0.09 & 0.33 & -0.32 & -0.41 & 0.09 & -0.35 & -0.18 & 0.14 & -0.12 & 0.32 & 0.03 & -0.00 & -0.02 & 1 & & & & & \\
\hline 17 & -0.43 & -0.30 & -0.28 & 0.18 & 0.10 & -0.30 & 0.62 & 0.12 & 0.10 & -0.09 & -0.11 & 0.40 & 0.13 & 0.62 & 0.60 & 0.18 & 1 & & & & \\
\hline 18 & -0.34 & -0.25 & -0.30 & 0.16 & 0.21 & -0.18 & 0.66 & 0.26 & 0.16 & -0.10 & -0.05 & 0.38 & 0.13 & 0.69 & 0.59 & 0.10 & 0.90 & 1 & & & \\
\hline 19 & -0.36 & -0.28 & -0.33 & 0.17 & 0.21 & -0.18 & 0.58 & 0.30 & 0.15 & -0.03 & -0.12 & 0.43 & 0.17 & 0.62 & 0.51 & 0.12 & 0.88 & 0.89 & 1 & & \\
\hline 20 & -0.11 & -0.14 & 0.04 & -0.17 & 0.05 & 0.05 & 0.37 & -0.05 & 0.06 & -0.18 & -0.04 & 0.19 & 0.40 & 0.37 & 0.39 & -0.03 & 0.22 & 0.24 & 0.22 & 1 & \\
\hline 21 & -0.12 & -0.26 & -0.32 & 0.02 & 0.26 & -0.05 & 0.45 & 0.36 & 0.21 & -0.16 & -0.11 & 0.23 & 0.24 & 0.52 & 0.44 & -0.00 & 0.68 & 0.67 & 0.66 & 0.20 & 1 \\
\hline
\end{tabular}


Table 8

Determinants of Hotel Performance

\begin{tabular}{|c|c|c|c|c|}
\hline & \multicolumn{2}{|c|}{ Sales per room } & \multicolumn{2}{|c|}{ Sales per outlet } \\
\hline & \multicolumn{2}{|c|}{ Random Effect } & \multicolumn{2}{|c|}{ Random Effect } \\
\hline & Coef. & Z-ratio & Coef. & Z-ratio \\
\hline Tax rate & -0.266 & $-1.65 *$ & -0.020 & -1.39 \\
\hline Gross Domestic Product growth & 0.371 & $4.94 * *$ & 0.100 & $3.26 * *$ \\
\hline Exchange rate & -0.000 & -0.38 & -0.000 & -0.19 \\
\hline Fuel price & -3.598 & $-1.66^{*}$ & -1.093 & $-2.55 * *$ \\
\hline Disposable income & 0.000 & $3.90 * *$ & 0.000 & $4.54 * *$ \\
\hline Number of natural disaster & -0.136 & $-2.02 * *$ & 0.022 & 1.16 \\
\hline Crime rate & -1.927 & -1.60 & -0.213 & -0.67 \\
\hline Number of other accommodation providers & -14.374 & $-3.24 * *$ & -4.575 & $-4.84 * *$ \\
\hline Number of competing hotel rooms & -0.000 & $-2.48 * *$ & -0.000 & -1.61 \\
\hline Performance of the overall hotel industry & 0.035 & $2.42 * *$ & 0.012 & $1.82 *$ \\
\hline Domestic tourist arrivals per capita & 0.016 & 0.99 & -0.001 & -0.34 \\
\hline International tourist arrivals per capita & 11.467 & $4.22 * *$ & 5.770 & $4.44 * *$ \\
\hline T\&T government expenditure & 0.514 & $2.29 * *$ & 0.274 & $2.23 * *$ \\
\hline Transparency of government policies & 1.557 & 1.11 & 0.056 & 0.14 \\
\hline Fairness in government spending & 3.048 & $2.14 * *$ & 0.327 & 1.17 \\
\hline Visa policies & 0.050 & $4.15^{* *}$ & 0.010 & $3.87 * *$ \\
\hline Quality of air transport infrastructure & 0.521 & 0.32 & -0.515 & -0.93 \\
\hline Quality of port infrastructure & 0.391 & 0.24 & 0.443 & 1.18 \\
\hline Quality of road infrastructure & -2.142 & -1.22 & -0.251 & -0.50 \\
\hline
\end{tabular}




\begin{tabular}{lcc|cc} 
Ease of hiring foreign labor & -1.828 & $-1.67^{*}$ & -0.410 & -1.63 \\
Quality of the education system & 2.145 & $2.08^{* *}$ & 0.693 & $1.88^{*}$ \\
\hline
\end{tabular}

Note: **Significant at the $5 \%$ level, *significant at the $10 \%$ level. 
Table 9

Elasticity of Key Determinants of Hotel Performance

Sales per room

Fairness in government spending $\quad 0.2552$

Quality of the education system $\quad 0.2421$

International tourist arrivals per $\quad 0.1514$

capita

Disposable income $\quad 0.1200$

Performance of the overall hotel $\quad 0.0786$

industry

Visa policies

0.0726

T\&T government expenditure

0.0465

Gross Domestic Product growth $\quad 0.0188$

Number of natural disaster $\quad-0.0189$

Number of competing hotel rooms $\quad-0.0236$

Fuel price $\quad-0.1141$

Ease of hiring foreign labour $\quad-0.1916$

Tax rate $\quad-0.2729$

Number of other accommodation $\quad-1.4898$

providers 


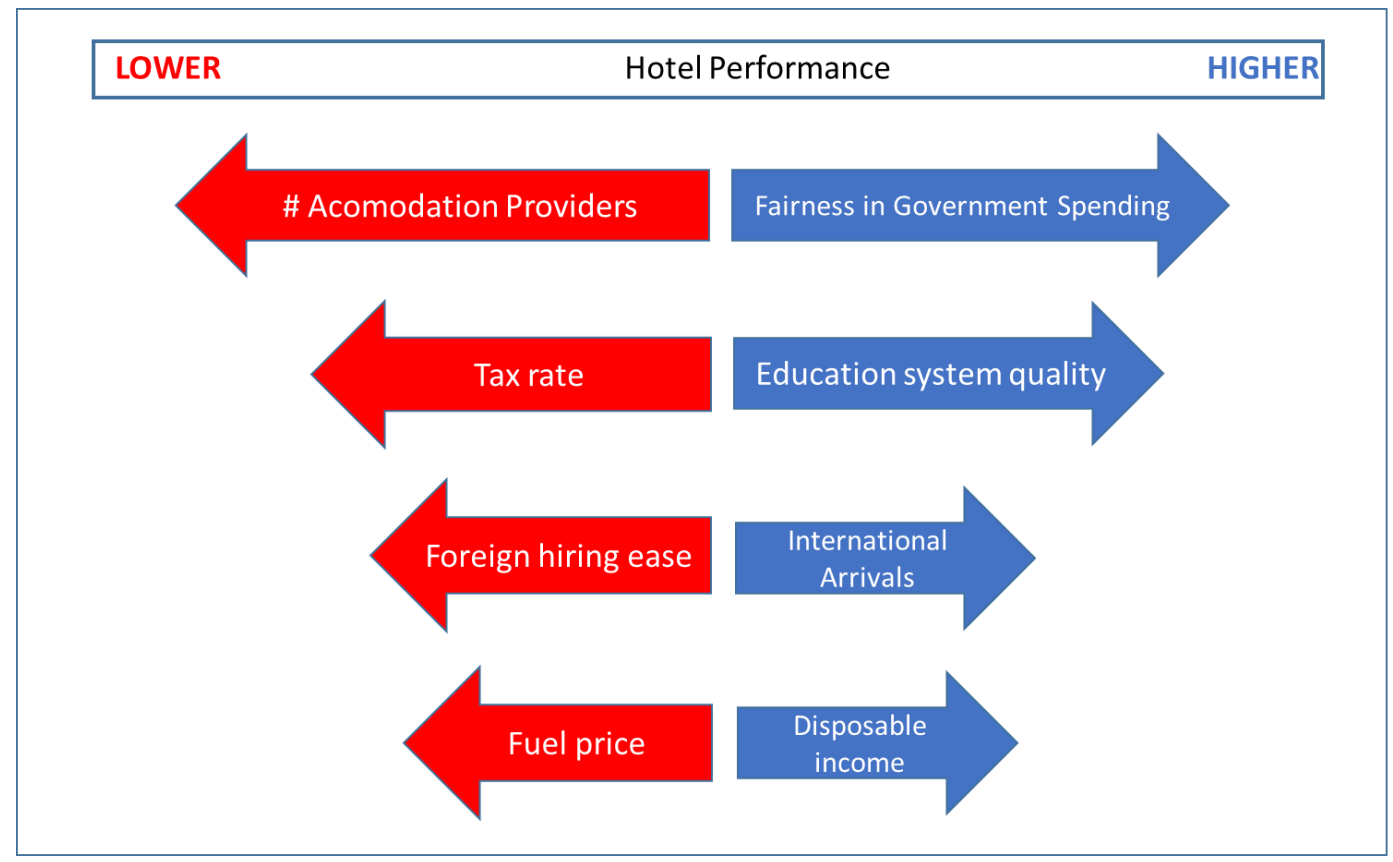

Figure 1. Key determinants of hotel performance (sales per room). 